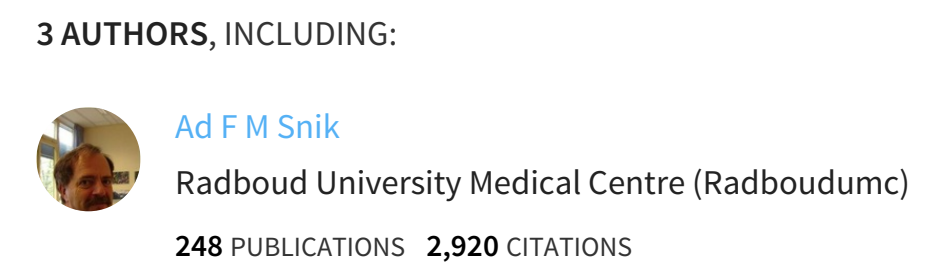

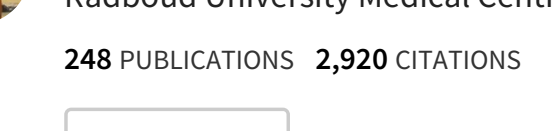




\title{
COCHLEAR IMPLANTATION IN DEAF CHILDREN
}

\author{
Mohammad J.A. Makhdoum, MBBS, AFsA; Ad F.M. Snik, MSc, PhID; Paul van den Broek, MD), liRes, Phl)
}

\begin{abstract}
A cochlear implant $(\mathrm{Cl})$ is a hearing device introduced in the 1980) for proloundly deat" subjects who gained little or no benelit lirom powerful hearing aids. This deviee eomprises an electrode anta inserted in the cochlea, connected to an internal receiver, and an externally worn speech processor. The cl transforms acoustic signals into electrical currents which directly stimulate the allditory nerve. Since the carly log(t), cochlear implantation in children hats been developing rapidly. Although it is still diflicult an prediet how a child will perform with a cochlear implant, the suceess of eochleat implantation can no longer be denied. In this paper, some recent papers and reports, and the results of the valtious Nijmegen eochlear implant studies. are reviewed. Issues about selection, examinations, surgery and the outcome atre disctissed. Overatl, our results were comparable with those of other authors. It ean be concluded that cochleal implantation is an effective treatment for postlingually deaf as well as prelingually (eongenital or acequired) deal" children with proliound

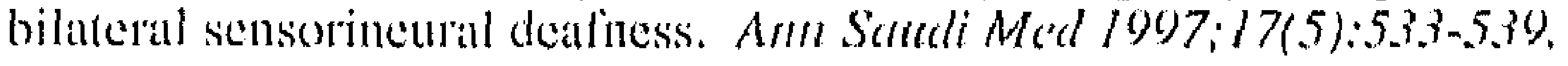

Cochlea implantation is widely accepted as a routine clinical procedure for selected deaf children. It restores deaf children's perception of sound through the use of a special electronic device. The $\mathrm{CI}$ system comprises an electrode (single or multi-channel) placed in the cochlea, connected to an implanted receiver, and an externally worn microphone, signal processor and transmitter. The speech processor analyzes the sound signal from the microphone and transmits it transcutaneously to the internal receiver. The electrical stimulation by the $\mathrm{Cl}$ bypasses the nonfunctional parts of the cochlea and delivers signals directly to the auditory nerve. Becaluse of the direct stimulation of the nerve, most $\mathrm{Cl}$ users perceive hearing sensations that cannot be obtained with even the most powerful conventional hearing aid. Owing to technological evolution, different types of $\mathrm{Cl}$ devices have been introduced. The diflerence between the various types is in the dectrode designs and/or speech processing strategies. However, they all consist of similar basic elements.

In recent years, remarkable progress has been made in the application of pediatric cochlear implantation, from the research stage to regular clinical application. At least 340) subjects under 18 years have received $\mathrm{Cl}$ worldwide. Of them, 4(0) were under the age of three years when implanted and a further 1250 were between three and six

From the Departments of Otorhinolinyghology. St. Radboud University Hospital (Drs. Makhdoum, Snik, Van den Brodk), Nijmegen, The Nedtertands and Alnour Specialist Hoxpital (Dr. Makhdoum), Makkah. Situcli Arabiat.

Address reprint repuests and correspondence to Dr. M.I.A. Makhdoum: Department of Otorhinolaryngology, St. Radboud University H(ospital, P.O. Bex 9) 101. (050) HB Nijmegen, The Netherlands.

Accepled fir publicalion 10) June 1997. Received 10 fobruary 1997. years.' The main goal of $\mathrm{Cl}$ application is to restore hearing in children with profound hearing loss, thus enhancing their ability to participate in aural-oral communication.

Studies have revealed that the majority of children using a $\mathrm{CI}$ with a prelingual (before three years of age) or postlingual (after three years of age) onsed of dealiness obtain signilicant benelit from this prosthesis. However, speech perception abilities vary widely, ranging from the simple identification of sounds to the recognition of normal open speech. "Most users benelit more firom their Cl than from conventional hearing aids. 1,3.7.8

The problem of post-implant, variable speech pereeption abilities eontinues to challenge reseanth teanns, and efforts are being made to lind a means of predieting the result prior to eochlailr implantiation. So fiar, no preoperative factor has been lound that can predict the outeome of eochlear implantation. However, it is known that some biographical litetor's, such ats ane at the omset of dealiness and the cluration of cleatiness, play a role."."

To obtain a good result, it is generally reported that carceful candidale selection is necessary, and that al rehabilitation program should follow cochlear implantation. Success in this fielel can mo longer be denied, in spite of initial skepticism in the scientilie world and the dealf community. ${ }^{10.11}$

This paper presents an overview ol the current concepts of ecochlear implantation and reviews the results of $\mathrm{Cl}$ studies at the University Hospital Nijmegen. In Nijmegen. the pedjatric cochlear implantation program was initiated in 1989 in elose cooperation with the Institute lor the Deal in St. Michielsgestel. Initially, the onc-channel Med. Bl device was used, but later on, the 22-channel Nucleus 
device was introduced. By the end of 1996, 44 profoundly deal" children had been implanted (Table 1).

\section{Selection Criteria and Preoperative Tests}

\section{Preoperative Assessments}

Pediatric cochlear implantation requires medical, aludiological and psychological evaluation. A routine ENT examination forms the initial part of the evaluation. Radical mastoidectomy or tympanoplasty, without any long-term problems, are not considered as contraindications. ${ }^{12,13}$ In general, preoperative audiological assessment is considered as the major factor to determine the suitability of a child for cochlear implantation. The audiological test batteries consist of play audiometry or visual reinforcement audiometry, tympanometry and speech perception tests. Audiological assessment should confirm profound, bilateral sensorineural hearing loss, without useful residual hearing. To determine the potential of residual hearing, the use of powerful hearing aids with an appropriate auditory rehabilitation period is essential. Generally, speech perception tests quantify a child's ability to use his/her residual hearing effectively. Such data obtained preoperatively are also valuable as a reference for comparison with postimplant scores. To confirm the results of behavioral hearing tests, objective electrophysiological tests, such as auditory brain stem response (ABR) and/or electrocochleography measurements, are often used. ${ }^{11}$

The radiologic evaluation includes high-resolution computed tomography (HRCT) scanning, which is a prerequisite to determine possible ossification of the cochlea and congenital anomalies as well als anatomical landmarks. ${ }^{1+17}$ Generally, ossification of the cochlea is not considered as a surgical contraindication for cochlear implantation. ${ }^{7,13.17 .18}$ However, in such cases full insertion of the electrodes is not always possible and the results of implantation might be poor.

Children undergo psychological testing as part of the preoperative assessment, to rule out any severe problems. The expectations and motivalion of the child and the parents have to be realistic. 7.19

\section{Evolution of the Selection Criteria}

Over the years, the selection criteria have changed as greater insight has been gained into the effect of several biographical factors upon $\mathrm{Cl}$ performanee. Various studies have revealed that postlingually deaf adults perform better with their $\mathrm{CI}$ than prelingually dealf adults.' The difference in performance between pre- and postlingually deaf children is far less pronounced. ${ }^{2.20}$ Prelingually deaf subjects who received an implant during childhood achieved a higher level of performance than those who
TAbl.1: 1. Biographical data on the children $(<14$ yrs) who recoived a cochlewe implant in Nijmegent.

\begin{tabular}{|c|c|c|}
\hline & Prolingual & Postlingtal \\
\hline Number ol clildren & 38 & 6 \\
\hline Male & 13 & 5 \\
\hline Female & 25 & 1 \\
\hline \multicolumn{3}{|c|}{ Age at onset ol deathess } \\
\hline Ratige, yrs & $0.01-2.9$ & $3.1-6.9$ \\
\hline Mein, yrs & 1.2 & 4.2 \\
\hline \multicolumn{3}{|l|}{ Duration of dealness: } \\
\hline Range, yl's & $1.9-1.3 .4$ & $1.3-7.9$ \\
\hline Mean, yrs & 5.4 & 4.4 \\
\hline \multicolumn{3}{|c|}{ Age al cochlear implantation } \\
\hline Range, yrs & 2.9 .1 .3 .4 & $4.3 \times 12.3$ \\
\hline Mealn, ylis & 0.6 & 8.6 \\
\hline \multicolumn{3}{|l|}{ Duration of CSI use } \\
\hline Ralnge, yt's & $0,5-6,9$ & $0.6-4.2$ \\
\hline Mcin, yes & 2.7 & 3.4 \\
\hline
\end{tabular}

received CI during adulthood."

Dowell et al. ${ }^{2}$ reviewed the speech perception results of all the children and adolescents (up to 19 years of age) implanted in Melbourne and Sydney. In agreement with other authors, they observed that the range of speech perception perlormance was wide. Their results indicate that the age at onset of hearing loss and the age at the time of cochlear implantation do not have any significant effect on speech perception. However, the duration of deafiness and the duration of implant use had a significant effect.

In the recent literature, the youngest children implanted were under two years. Implantation at such a young age is only feasible if profound bilateral sensorineural hearing loss can be diagnosed with complete certainty, and if the child has not benefited from conventional hearing aids. Cochlear implantation at a young age may minimize the negative effect of auditory deprivation and in the calse of meningitis, it might help to prevent labyrinthitis ossification which would impede later implantation. Cohen and Waltzman" reported that eight children under two years received $\mathrm{Cl}$ at their institute and all showed signilicant benelit. The Hannover group has also implanted such young children, with encouraging results (personal communicalion). Nevertheless, more data are required to show the benefits of early implantation and help to guide future policy.

\section{Surgery}

\section{Surgical Tec/mique}

CI surgery can be perlormed successfully in children, in spite of some difliculties, particularly with an ossified cochlea. ${ }^{18}$ Access to the cochlea is obtained by a mastoid and facial recess approach, as is used in surgery 

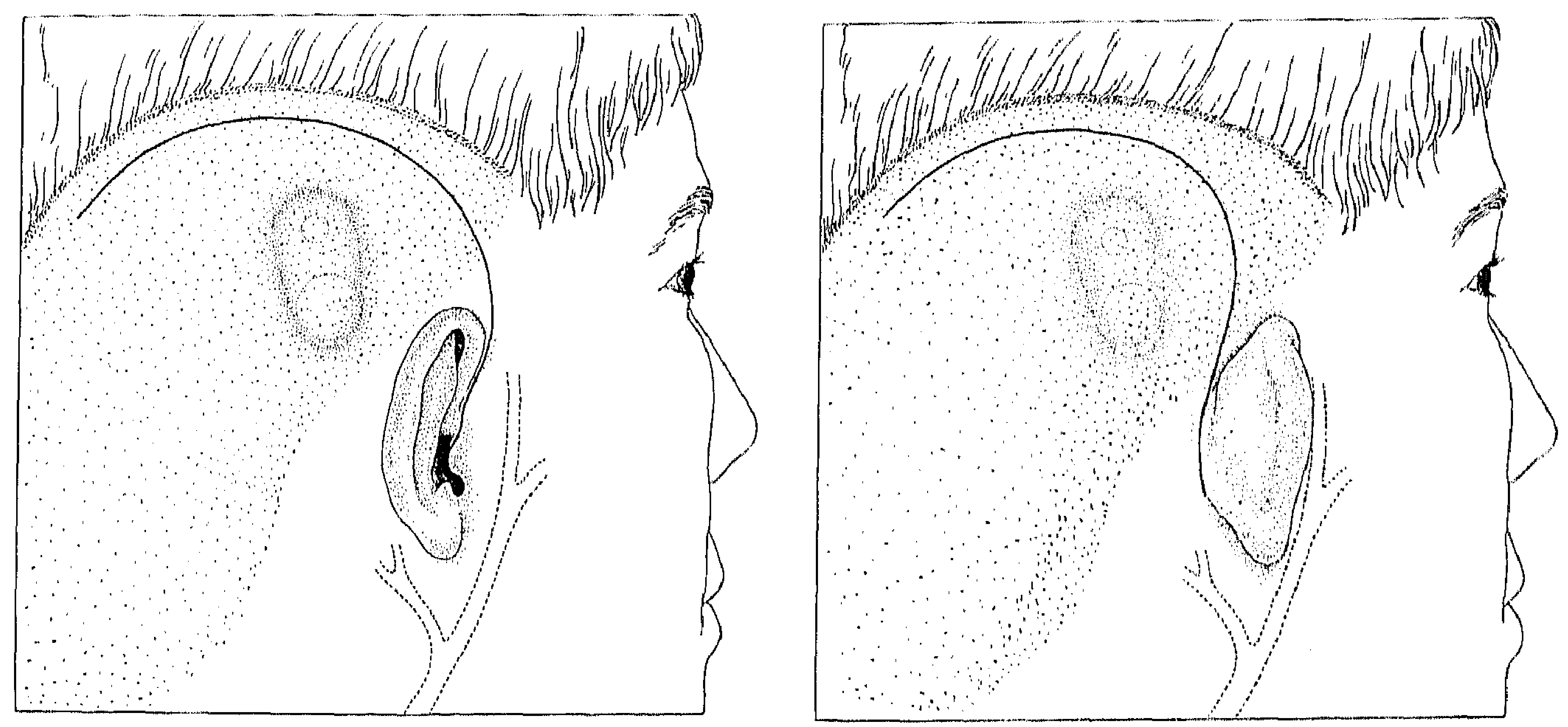

FIGURE IA. Diagram of an endaural incision. IB. A retro-iluricular incision employed for cochlear implantation. Condensed dots indicate the site of placement of the receiver.

for chronic otitis media. The receiver-stimulator is positioned just above and behind the pinna (Figures $1 \mathrm{~A}$ and (B). The incision should be made at least $1 \mathrm{~cm}$ away from the planned site for the internal receiver. Several types of skin nap design have been advocated, and the basis for the designs is to maintain a good vascular supply to the flap.

In Nijmegen, two types of incision are used: an endaural incision (Figure $1 \mathrm{~A}$ ) or a retro-auricular incision (Figure (B). Both curve upwards and backwards, high over the parietal region. Due to the dimension of a child's skull, the thinness of the skin and the later growth of the skull, the incision is made right down to the bone. The temporal muscle is lifted from the parietal portion of the temporal bone, with the subcutaneous tissue and skin as a single layer flap. This surgical modification minimizes problems with wound healing and possible electrode extrusion.

After elevation of the skin flap, the dura mater is sometimes exposed when drilling the well for placing the receiver-stimulator. It is usually necessary to gently push the dura mater down with a thin piece of bone to accommodate the receiver coil. Following mastoidectomy, a facial recess approach is used to gain access to the middle ear and round window niche. ${ }^{21}$ The facial recess is opened, the facial nerve is skeletonized, avoiding exposure of the nerve sheath. Cochleostomy can be performed in two ways: through the promontory anterior to the round window membrane, or through the round window membrane itself. ${ }^{11,21}$ The electrode array should be inserted gently to prevent damage to the delicate cochlear structures as much as possible.

Ossification of the cochlea, as is often found in postmeningitis cases, needs drilling to open the scala tympani for insertion of the electrode array. In some cases with severe ossification, extensive drilling of 6 to $8 \mathrm{~mm}$ is necessary. If no fluid-filled lumen is found, this maly result in partial insertion. ${ }^{15}$ Hartampl et all. ${ }^{18}$ reported that in cases with cochlear ossification, at feast seven electrodes of the Nucleus 22-channel system can be inserted. Alter insertion, the cochleostomy is sealed with bone dust or soft tissue and glue. In general, the electrode lead is placed in a groove created in the superior part of the mastoidectomy fossa and lixed in the fossa incudis. This is hecause the distance from there to the round window does not change after birth. The receiver-stimulator should be tied down securely.

\section{Complications:}

The surgical complication rate of the implant procedure is low in children. Largely, the emplicaltions are comparable with those of middle ear surgery. In addition to surgical complications, device migralion or litilure may occur. No major complications oceurred in any of the 44 children who received a $\mathrm{Cl}$ in Nijmegen. However, postoperative complications were found. A minor wound infection occurred in one child, while another child hatd at surgical hematoma. In live children, only partial insertion of the electrode arraly was possible due to severe ossification of the cochlea. 
Revision surgery can be performed either to upgrade the $C I$ system or to replace a failing device. It is possible to explant and reimplant without damage to the ecchlea or the atuditory nerve. ${ }^{21}$

\section{Preoperative Imaging and Surgical Results}

HRCT scanning has proven to be a valuable tool for the preoperative alssessment of cochlear patency. However, minor or major cochlear ossification encountered during surgery is not always visible on preimplant radiological studies. ${ }^{13,17,22}$ If the HRCT scan seems to be normal in children with a bistory of meningitis, the surgeon should suspect obliteration of the round window and part of the basilar turn.

A Dutch study on the predictive value of HRCT scanning carried out in 88 subjects (children and adults) with a $\mathrm{Cl}$ showed a relatively large number of falsenegatives, mainly in children, when compared to the intraperative findings. The datal are presented in Table 2. This means that in spite of its value, the aceuracy of preoperative HRCT scanning is not optimal.

\section{Electrophssiological Mecasurements}

To achieve the best results with a $\mathrm{CI}$, it is important to adjust the processor outpul to the user's dynamic range. This maly be a problem in young children. ${ }^{23}$ To tackle this problem, several investigators performed measurements to assess threshold and comfortable levels directly after placement of the $\mathrm{CI}$, while the child was still under general anesthesia. For this purpose, electrically evoked ABR measurements (EABR) and/or electrically evoked stapedius nuscle reflex (ESR) measurements were porformed. ${ }^{23.24}$

A technical restriction of the EABR measurement is that it is more susceptible to noise and electrical artilacts than the ESR measurement. A specilic problem with intrapperative ESR measurement is that anesthetic agents influence the outcome. ${ }^{24.25}$ To illustrate this, Figure 2 shows an example of ESR thresholds recorded intraperatively. During the measurement, the concentraltion of an anesthetic agent (Haloshane) was increased and later readjusted to the original level. A signifieant elfect of the Hakthane concentration wass seen. Figure 2 also shows the postoperative valle obtalined six months after device lining. In general, postoperative ESR thresholds were lower than lhose measured during surgery." Owing to the lechnical restrictions and the poor relationship with the behavioral results, intraoperative EABR and ESR data should be used with caution for device programming.

\section{Rehabilitation}

The am of the rehabilitation program is to achieve

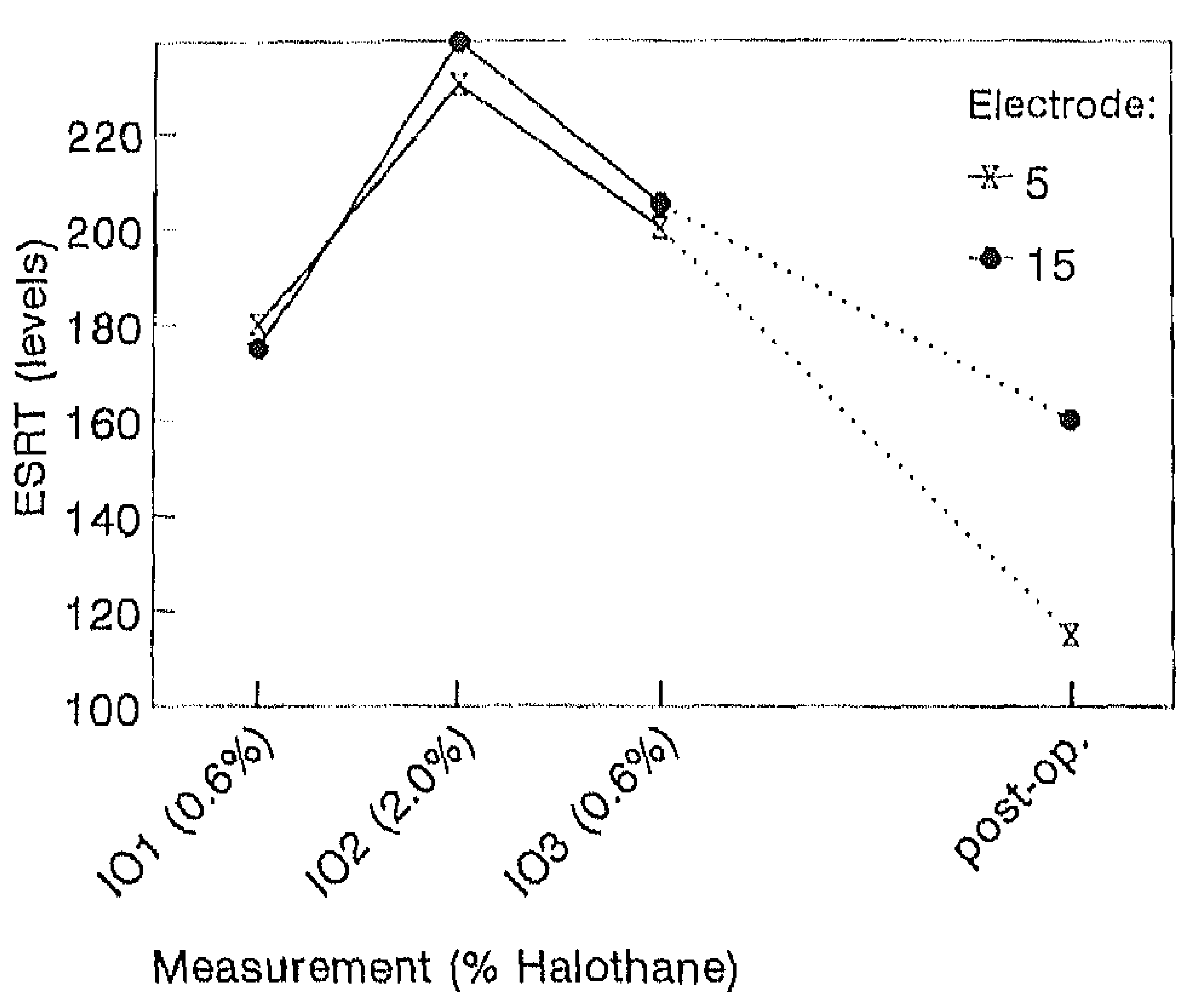

PIGURE 2. A typical example of electrical-evoked stapedius rellex lluesholds (ESRT) recorded inmoneratively from clectrodes 3 and 20, while the emeentration ol the anesthetie agent (Hatothane) was varied from $0.6 \%$ (IO1) 10 2.0\% (IO)2) and back again 60 0.6\% (IO3). Postoperative restals obtained six months after device litling arce also indicated.

optimal use of a $\mathrm{Cl}$. New auditory abilities should be utilized to develop new auditory and communication skills. Generally, speech perception skills improve after cochlear implantation. After the initial rehabilitation period, normal learning in daily life contributes to the optimal use of a CI. ${ }^{14}$

Collaboration of the Cl team with tutors in a setting for the deall is essential, especially for children. Il a child does not receive rehabilitation and encouragement for spoken language, the outcome of echlear implantation is likely to be disappointing. In cooperation with the Institute for the Deall in St. Michiclsgestel, the initial rehabilitation period in Nijmegen takes two weeks. After this period, implanted children return once every month for tutoring for at least one year. Alter rehabilitalion, they should be able to continue learning at home and al school, at their own speed and in their own mamner.

\section{Outcome of Cochlear Implantation}

Several studies have focused on speech perception skills in children with a $\mathrm{Cl}$. Gintz et al. ${ }^{20}$ studied the benefit of the Nucleus multichannel $\mathrm{Cl}$ in 54 children. They found that the speech perception skills of postlingually deal" children improved significantly during the fir'st year after implantation. The prelingually deaf children progressed al a slower rate than their postlingual counterparts. However, some of the prelingually deat children altained comparable, and in some instances better, 


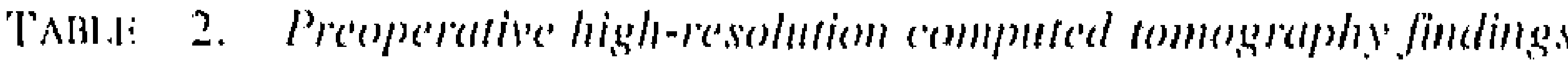

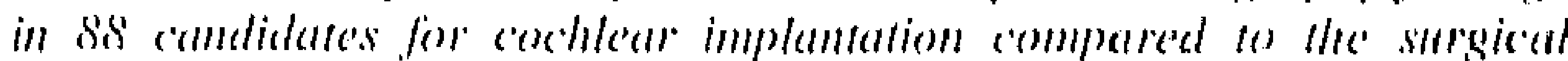
findings.

\begin{tabular}{lccc}
\hline & $\begin{array}{c}\text { Adults } \\
\text { HRCT sean }\end{array}$ & $\begin{array}{c}\text { Children } \\
\text { HRCT scan }\end{array}$ & $\begin{array}{c}\text { Totil no. of } \\
\text { subjects }\end{array}$ \\
\hline True-positive finding & $7(11.3 \%)$ & $4(1.5 .4 \%)$ & $11(12.5 \%)$ \\
False-positive linding & $5(8.1 \%)$ & $1(3.8 \%)$ & $6(0.8 \%)$ \\
True-negative findling & $39(62.9 \%)$ & $12(46.2 \%)$ & $51(58 \%)$ \\
Falsc-negative finding & $11(17.7 \%)$ & $9(34.6 \%)$ & $20(22.7 \%)$ \\
Total & 62 & 26 & 88 \\
\hline
\end{tabular}

speech understanding than some of the postlingually deat children. These authors also observed that speech perception and speech production continued to improve over the live-year follow-up period. The majority of the children showed open-set speech recognition. Waltzman et al." analyzed the postoperative speech performance of 14 congenitally and prelingually hearing-impaired children whose age at the time of cochlear implantation was under three years. All the children developed good auditory skills. In addition, they concluded that congenitally and prelingually deaf children should receive a $\mathrm{CI}$ at an early age, because it will be more beneficial for the development of speech perception and because there was no difference in performance between the congenital and prelingual groups. It has become firmly established that the perceptual abilities of children with a $\mathrm{CI}$ continue to improve significantly over time. This is in contrast with proloundly deaf children who use conventional hearing aids, as they show plateau scores. ${ }^{3.8}$

Miyamoto et al. ${ }^{20}$ compared the results of matched groups of $\mathrm{Cl}$ users and hearing aid users. They showed that the mean score on speech perception tests 2.5 years after implantation was obviously better than the average score of children with conventional hearing aids with a hearing loss between 9() and $1(0)$ dB HL.

With regard to speech production, the earlier that cochlear implantation is performed in children, the better the intelligibility of their speech. Osberger et al. ${ }^{27}$ reported that children with early onset of deafness who were implanted before the age of 10 years proclueed good intelligible speech, whereas a similar group of children who received a cochlear implant after the age of to years had the poorest speech intelligibility.

The auditory skills of 21 children with acquired profound deafness caused by meningitis, implanted in Nijmegen with a Nucleus multichannel system, were evaluated. These children were divided into four groups. The first group comprised children who became deal between 0.3 and 2 years $(n=5)$, the second group comprised children who became deal between 2.1 and 3 years $(n=6)$, and the third group comprised children who were older than 3 years at the onset of deatness $(n=5)$. All these children had the electrode inserted over its full length. The fourth group comprised children who became deat between 0.6 and 2.7 year's of ang $(n=5)$ and who had only partial electrode insertion due 10 severe cochlear ossification. Preoperatively, the hearing thresholds were above 120 dB HL for all the children. The preoperative speech perception testing was carried out using high-gain postauricular hearing aids that the children had been wearing daily for at least one year. No signilicant speech pereeption using auditory presentation only (no lipreading) was found in any of the childen.

Alter cochlear implantation, multiple speech performance measurements were condueted to determine the long-term trenefits of rehabilitation with the CI. T'wo of the speech perception lests used were a picture-word identification test, which wats a elosed-set test of 12 monosyllables, and an open-sed word recognition test, which consisted of 30 monosyllables. All test words were presented in auditory mode only, at normal conversational level of $70 \mathrm{~dB}$.

Remarkable improvements in speech recognition performance were observed in the three groups of children with full insertion. Figure 3 shows the mean scores of these three groups on the picture-word identilication test and Figure 4 shows the mean scores of the open-set word recognition test as a lunction of follow-up. There was constant improvement during the whole evaluation periol. The most pronounced improvements were observed in the group of ehifden who became deall aller the age of three years. Figure 4 shows that alter three years of follow-up? the mean open-set speed recognition seore lies between $55 \%$ to $75 \%$. This is of greal importance, becatuse most children with such speech recognition abilities atre able to develop normal oral-ilural communication. ${ }^{1,6.8}$ Several of these children can communicale with their rolatives by telephone. These open-set speech scores are typically found in hearing impaired subjects with a hearing loss of $0.5 \mathrm{lo}$ $80 \mathrm{~dB} \mathrm{HL}$, using well-fitted conventional hearing aids." So. the CI users perform with their Cl alter lloree yeats ats well as well-litted hearing ald users with a hearing loss between 65 and 80 dB HL. The age at onsed of the deathess seens to aflect the progress of the child (Figures 3 and at). The ligures suggest that the chiblen who became deal' relatively earlier in life (group with onsed of clealiness between 0.3 and 2 years of age) and who had therefore litule previous aluditory experience, only showed delayed scores compared to children who acquired specel belore they became deal' (group with onset of dealness alter thee years of age).

The result of the fourth group, with partial electrode insertion, was much poorer. The children in this group had scores below $10 \%$ on the open-sed and closed wordidentilication tests, even alter three years of follow-up. 


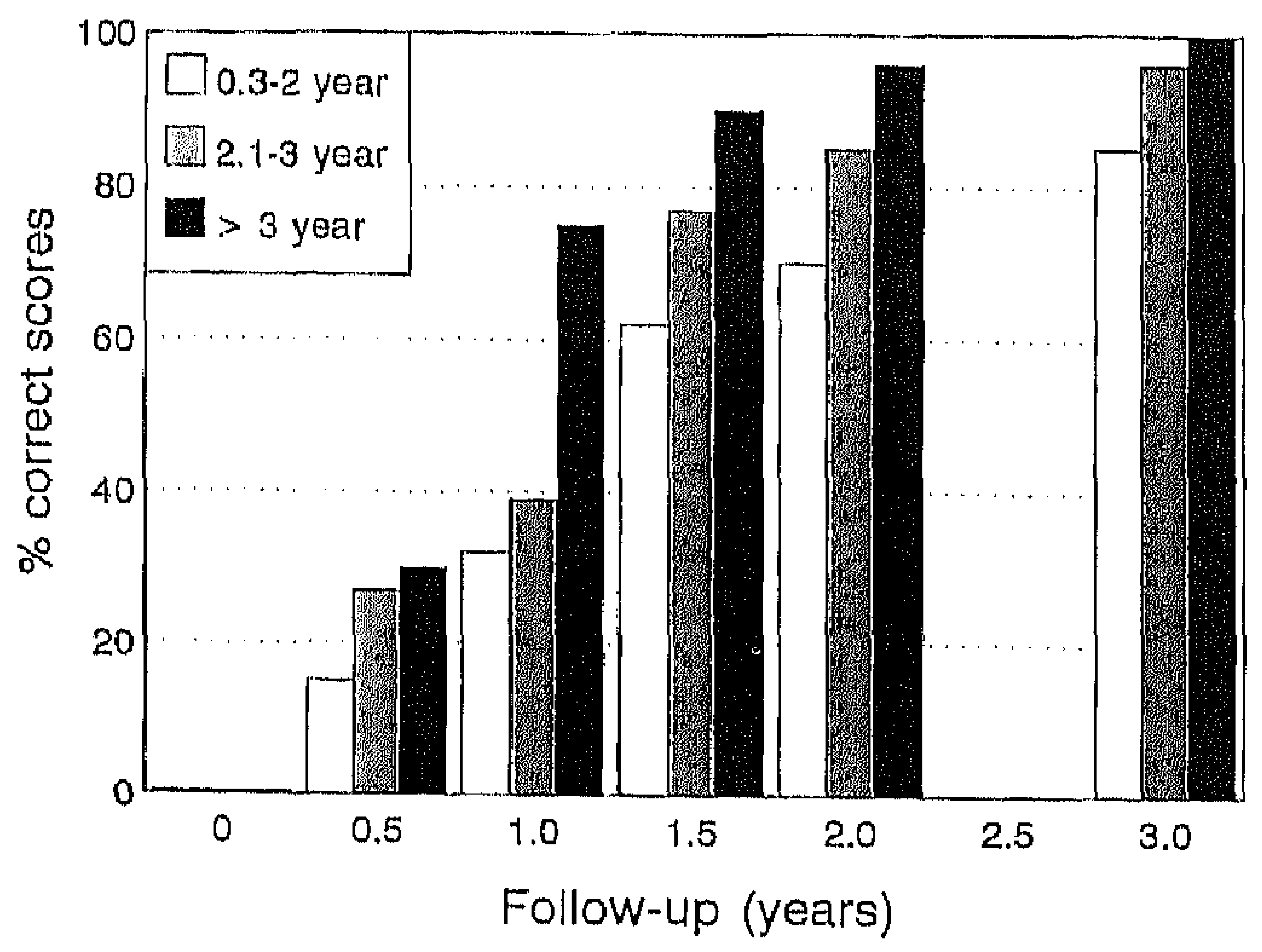

FIGURE 3. The mean score on the picture-word identification test as a function of follow-up of the three groups of children with full electrode insertion subdivided according to their age at the time of onset of deafness. The white bars indicate the mean scores of the cliildren with acquired deafness between 0.3 and 2 years of age $(n=5)$. The gray bars indicate the mean scores of the children with acquired deafness between 2.1 and 3 years of age $(n=6)$ and the black bars indicate the mean scores of the children whose age at the onset of deafness was above 3 years $(n=5)$. The values at a follow-up of 0 are the mean scores obtained before surgery with the children's own previous conventional hearing aids.

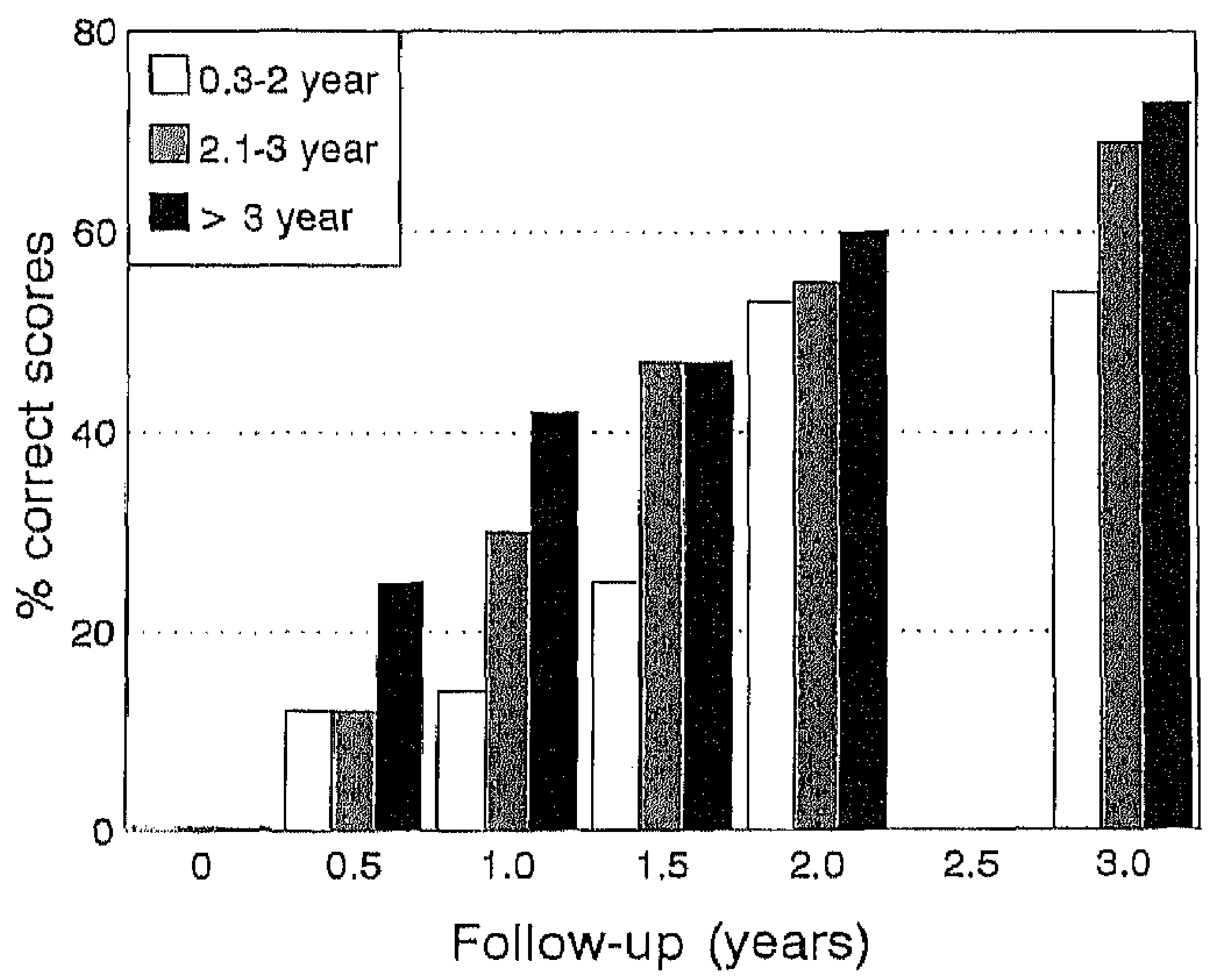

FIGURE 4. The mean score of the open-set speech perception test as a liunction of follow-up of the three groups of children with full electrode insertion sublivided aceording to their age at the time of deafness. The white bars indicate the mean scores of the children with acquired deafness between 0.3 and 2 yeatrs of age $(n=5)$. The gray bars indicate the mean scores of the ehildren witl acquired deafness between 2.1 and 3 years of age $(n=6)$ and the black bars indicate the mean scores of the children whose age at the onset of dealness wats above 3 years $(n=5)$. The values at a follow-up of 0 are the mean scores obtained before surgery with the children's own previous conventional hearing aids.
Therefore, results of a more basal speech perception test will be presented. The test used was a supra-segmental test in which the children only had to identify the number of syllables per word. Figure 5 shows the range (vertical lines) and the mean scores of the partial insertion group (white bars) and the average of the other three groups (gray bars). The values at the beginning of the follow-up are the mean scores obtained before surgery from the children with their own previous conventional hearing aids. This figure illustrates that the children with partial insertion are relatively poor performers, even after a threeyear period of daily use. Therefore, to achieve the best result, the electrode array should be inserted into the cochlea over its full length. However, this cannot al ways be achieved in the case of severe ossification of the cochlea. Nevertheless, Kemink et al. ${ }^{28}$ reported that the performance of children with partial insertion was comparable to that of children with full insertion. Our findings and those of other groups ${ }^{11,29}$ showed that partial insertion leads to inferior long-term results.

In summary, our results and those of other studies ${ }^{1,3,6}$ showed that significant (but variable) cochlear implantation outcomes can be achieved in children. The age at the onset of deafness and the method of insertion of the electrode array, either fully or partially inserted, play a role.

\section{Conclusion}

Nowadays, cochlear implantation is generally considered to be of significant value for pre- and postlingually profoundly deaf children. Adequate rehabilitation is most crucial for the children to maximize the benefits of cochlear implantation. Many studies reported that auditory performance with a $\mathrm{CI}$ varies among children. Until now, there has been no completely satisfactory explanation for this observation. However, performance seems to be best in children with a short duration of deafness, who acquired speech and language before their deafness occurred. Present results suggest that such children may acquire good speech perception and as a result, may develop normal aural-oral communication.

The outcome of partial insertion of multichannel electrode arrays is generally poorer than that of full insertion. This will depend on the position and number of active electrodes. It is highly questionable whether cochlear implantation in a severely obliterated cochlea is worthwhile.

Over the years, inclusion and exclusion criteria have gradually changed with growing knowledge. Generally, etiology and age at implantation do not seem to affect the post-implantation auditory performance. However, the earlier the implantation, the better the result, especially in prelingually deaf individuals. Nowadays, most Cl teams 


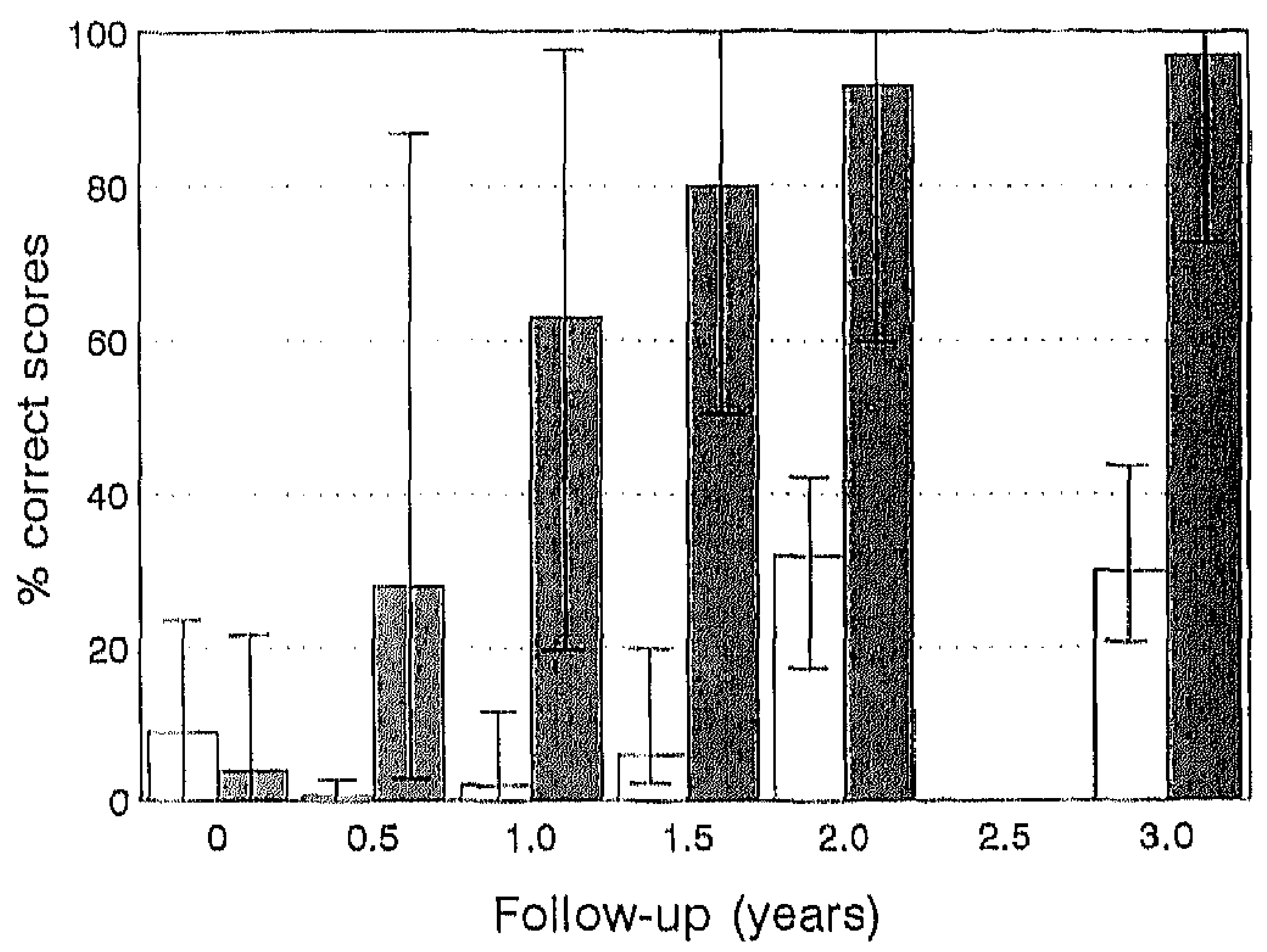

FIGURE 5. The mean score on the supri-segmental speech identification test and its range for the children with partial electrode insertion (white bar) and the averaged mean scores of the three groups of children with full insertion (gray bar) during a three-year follow-up period alter cochlear implantation. The vertical lines indicate the range in the oblained scores. The values at follow-up of 0 are the mean scores obtained before surgery with the children's own conventional hearing aids.

only use a limited number of exclusion criteria. The most important exclusion criterion is the ability to utilize any residual hearing with well-fitted conventional hearing aids.

Owing to technological evolution and an increase in experience, the era of cochlear implantation is advancing rapidly. New techniques may enable wider groups of preand postlingually hearing-impaired children to benefit from cochlear implantation.

\section{References}

1. Summerlield $A Q$, Marshall DH. Cochlear implantation in the UK 1900-1994. Londom: HMSO, 1995.

2. Dowell RC. Blamey PJ, Clark GM. Potential and limitations of cochlear implants in children. Ann Otol Rhinol Laryngol 1995:104 Suppl 166:324-7.

3. Miyamoto RT, Kirk KI, Todd SL, Robbins AM, Osberger MJ. Speedh pereption skills ol children with multichannel cochlear implants or hearing aids. Ann Otol Rhinol Laryngol 1995;104 Suppl 160:334-7.

4. National Institutes of Health Consensus Statement. Cochlear implants in adults and children. 1905;13:1-30.

5. Tyler RS. Cochlear implants and the deall culture. Am J Audiol 19) $3: 2: 26-32$.

6. Wallaman SB, Colen NL, Gomolin RH, Shapiro WH, Oxdamar SR, Hoffman RA. Long-term results of early cochlcar implantalion in congenitally and prelingually deafened children. Am J Otol 1994:15 Suppl 2:9-13.

7. House WF, Berliner KI, Luxlord WM. Cochlear implants in deat" children. Curr Prob Pediatr 1987:17:345-88.

8. Snik AFM, Vermeulen AM, Geelen CPL, Brokx JPL, Van den Broek P. Speech perception performance of children with a cochlear implant compared to that of children with conventional hearing aids. Part 2: results of prelingually deaf children. Acta Otolaryngol (Stockh), in press 1997
9. Walloman SB, Fisher SG, Niparko JK, Cohel NL. Preclictors of postoperative performance with cochlear implants. Ann Otol Rhinol Litryngol 1995:104 Suppl 165:15-8.

10. Cohen NL, Waltaman SB. Cochlear implants in inlants and young children. Seminats in Hearing 1996;17:215-21.

11. Van den Broek P, Cohen N, O'Donoghue G, Flaysse B, Laszig R, Offeciers E. Cochlear implantation in children. J Pediatr Otorhinolaryngol 1995;32 (Suppl):217S-23S.

12. Gantz B.J. Issues of candidate selection for a cochlear implant. Otolaryngol Clin North Am 1989;22:239-47.

13. Schwartzman JA. Avoidance of complications with exchleal implants. Ann O(ol Rhinol Laryngol 1995:104 Suppl 166:431-2.

14. Dahm MC, Diettich B, Reich A, lentu\% 'T'. The accurney of preoperative high-resolulion computed tomography in predieting cochlear pathology. Aclv Otorhinolatyngol 1095:50:25-30).

15. Gay RF, Evans RA, Freer CEl, Sylowico HE, Maskell GF, Racliology for cochlear implants. J Laryngol Otol 199) 1;105:85-8.

16. Phelps PD. Cochlear implants for engenitul deformities, J Lanyngol O(o) 1992;106:967-70.

17. Wiet R.J, Pyle GM, O'Connor CA, Russell E, Schramm DR. Computed tomogmphy: how accumate a predictor for coelleall implantation? Laryngescope 1990;100:687-92.

18. Hartampf $R$, Weber $B$, Dahm $M C$, Lenarz $T$ ', Management of obliteration of the codblea in eodalear implantation. Ann Otol Rhinol Latryngol 1995:104 Suppl 160:416-8.

19. Vermeulen A, Brokx J, Coninx F, Van der Harten J, Peters-Bos M. A global approach in atuditory rehabilitation. In: Hochmair-Desoyer, [J, Hochmair, ES. Advances in cochlear implants. Vienna: Manz, 1994; 584-5.

20. Gantz. BJ, Tyler RS, Woodworth GG, Tye-Murray N, Fryauf-Bertschy $H$. Results of multichannel cochlear implants in congenital and acquired prelingual dealness in children: live-year follow-up. Am J Otol 1994:15 Suppl 2:1-7.

21. Clark GM, Cohen NL, Shepherd RK. Surgical and safely considerations of multichannel cochlear implants in children. Ear Hear 1991;12 (Suppl): 1.5S-24S.

22. Dobic RA, Jenkins H, Cohen NL. Surgical results. Ann Oul Rhinol Latryngol 1995:104 Suppl 105: 6-8.

23. Mason SM, Garnbam CW, Sheppard S, O'Ionoghue GM, Gibbin Kl' An intraperative test protocol for objective assessment of the Nucleus 22-channel cochlear implant. Cochlear implants in children. Ady Oto Rhino Laryongol 1995:50:38-44.

24. Van den Borne B, Snik AFM, Mens L.dM, Brokx JPL, Van den Broek P. Stapedius reflex mensurements during surgery for cochlear implantation in children. Am J Otol 1096:17:554-8.

25. Gnakdeberg D, Batmer RD, Lullwit\% L, Latsig R, Dybus U, Lenary, 'T', Der Einfluss der Narkose auf den intranoperativ elektrisel atusgelosten

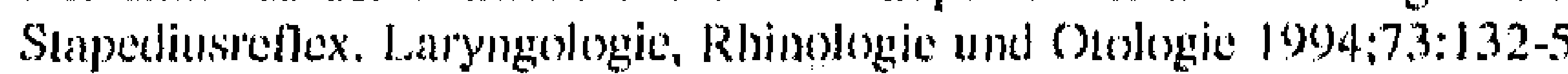
(in German).

26. Miyamoto R'l, Osberger M.I, Todd SL. Robbins AMI. Speech pereeption skills ol children with multichannel cochlear inplants. In: IochmailDesoyer IJ, Hochmair [SS. Aovanees in cocillear implants. Vienna: Mallz. 1994:4088-502.

27. Osberger MJ, Matso M. Sam L.K. Speedn intelligibility of elilden with cochlear implants, atetile atids, or hearing aiks. I Spreeth Hent Res 109) 3:36:186:203.

28. Kemink JL. Zinnmernan-Plitlips S. Kileny PR, lïrs/ JB, Novak MA. Auditory perlormanec ol chilelren with cochlear ossilication and partial implant insertion. Laryngoseope $1002: 1(12 ; 100) 1-5$.

29. Cohen $\mathrm{Nl}$, Wallizman, SiB. Partial insertion of the nucleus multichannel cochlear implant: lechnigue and results. Am J Otol $1903: 14: 357-61$. 